\title{
Fronteiras - Revista Catarinense de História/ANPUHSC - n.29
}

\section{Apresentação}

Pesquisas recentes no campo da História da Educação e História do Ensino de História indicam que a escola é um espaço político. Tal característica, ainda que não seja exclusiva do tempo presente, tem sido objeto de disputas bastante acirradas. Práticas docentes, conteúdos ministrados e mesmo a função de uma formação cidadã emergem como passíveis de questionamentos e judicialização por parte de setores conservadores da sociedade, inclusive por meio de projetos de lei apresentados por iniciativas como "Escola sem Partido", que visam, entre outras questões, o cerceamento da autonomia docente e a retirada de referências à identidade de gênero, diversidade e orientação sexual dos Planos Estaduais e Municipais de Educação. Nesse sentido, O número 29 da revista Fronteiras, a Revista Catarinense de História, traz o Dossiê Ensino, Gênero e Diversidade: embates contemporâneos, cujo objetivo é promover espaço para os debates contemporâneos a respeito das questões políticas, de gênero, sexualidade e das relações étnico-raciais em suas diferentes possibilidades de articulação com o espaço escolar.

Em Ditadura militar e relações de gênero: problematizando o ensino de História por meio das ideias históricas de estudantes do Ensino Médio, Elaine Prochnow Pires e Cristiani Bereta da Silva analisam as ideias históricas de jovens estudantes do ensino médio de uma escola estadual de Santa Catarina a respeito dos conteúdos sobre a ditadura militar brasileira (1964-1985) com o objetivo de discutir as representações das mulheres e das relações de gênero no ensino de história do Brasil. As autoras propõem uma sequência didática que problematiza as narrativas construídas pelos(as) estudantes sobre o tema, visando refinar sensibilidades e desenvolver olhares mais críticos sobre questões de gênero, feminismos e história das mulheres.

Vanderlei Machado e Carla Simone Rodeghero apresentam Os Livros didáticos e a História da participação das mulheres no Movimento Estudantil, artigo no qual analisam a maneira como onze livros didáticos de história (distribuídos pelo PNLEM/2008) abordam, por meio de textos e imagens, a participação feminina no movimento estudantil brasileiro entre os anos de 1964 e 1968. Para os autores, o número de pesquisas que abordam participação feminina no movimento estudantil no Brasil cresce, no entanto, referências veiculadas nos livros didáticos ainda são poucas. 
Em Da teoria à prática: gênero, saberes docentes e desafios contemporâneos, Cintia Lima Crescêncio discute as contradições de nosso tempo presente marcado, por um lado, pelo fortalecimento dos estudos de gênero e consequente conquista de espaços no campo do ensino, especialmente por meio da formação de professores e, por outro, pela ascensão de projetos de lei com características conservadoras, inspirados em programas como o Escola sem Partido.

Ana Maria Marques, por intermédio da análise de duas telas históricas de Moacyr Freitas, apresenta debates referentes às questões de gênero e étnico-raciais em Havia uma Rosa e uma Vitória na representação pictórica da História de Mato Grosso. A autora propõe a desconstrução de violências, dentre as quais as de gênero, ao analisar as duas únicas telas do acervo do autor em questão que trazem mulheres como protagonistas.

Ainda alinhado a proposta deste dossiê, apresentamos a tradução do artigo "Não ensinamos mais a história da França na escola!" Mas ensinamos o que então?, de Henry Rousso. Neste, o autor posiciona-se diante de uma querela ocorrida na primavera francesa de 2015 a respeito de novos programas de História que deveriam nortear o ensino escolar da disciplina. Tal texto possibilita-nos pensar acerca de questões como as potencialidades do ensino de história e, consequentemente, de seus diversos usos políticos.

Na seção Artigos, Thiago Reisdorfer, em Uni-la: O processo de construção de uma universidade intercultural para a integração latino-americana, assume a instituição universitária e suas diferentes dimensões como objeto de pesquisa e analisa a formação da Universidade Federal da Integração Latino-Americana, percebendo-a pelo viés da integração intercultural.

Daniela Queiroz Campos, em Garotas de papel: a arte gráfica e os traços de Alceu Penna trata da produção gráfica de Alceu Penna. Através da análise meticulosa de colunas e daquilo que as caracteriza - diagramação, cores, imagens, traços, qualidade de impressão - apresenta um panorama sobre a arte gráfica brasileira no século XX e problematiza elementos concernentes ao reconhecimento e/ou possibilidade de enquadramento de Penna como designer.

O artigo Transformações urbanas na cidade de Florianópolis (1989-2011): a derrubada do Bar do Chico no bairro Campeche, de Carolina do Amarante e Luciana Rossato, discute as mudanças na cidade de Florianópolis, desde a década de 1980, a partir da análise dos discursos veiculados nos jornais. Para as autoras, os textos 
jornalísticos promovem e defendem a necessidade de preservar a identidade e a cultura açoriana, ao mesmo tempo em que a cidade e seus bairros costeiros como, por exemplo, o Campeche, passam por transformações devido ao crescimento populacional decorrente do desenvolvimento do turismo. O caso do Bar do Chico, construído na década de 1980 e demolido vinte anos depois, torna-se exemplificativo para a análise em questão.

Karla Simone Willemann Schütz, em "Uma incursão estranha”: a história oral na UFSC e as entrevistas de Simão Willemann (década de 1970), examina aspectos da criação e da trajetória do Laboratório de História Oral da Universidade Federal de Santa Catarina e mapeia alguns dos pressupostos que orientaram seu estabelecimento. Para tanto, parte de um estudo realizado sobre as pesquisas desenvolvidas pelo historiador catarinense Simão Willemann durante a década de 1970, em diálogo com publicações brasileiras sobre história oral, editadas no país entre as décadas de 1970 e 1990.

Na seção Resenhas, Natan Alves David realiza uma análise de Um país impresso: História do Tempo Presente e revistas semanais no Brasil, publicação de 2014 organizada por Silvia Maria Favero Arend. Ana Terra de Leon resenha Vigiar e Medicar: estratégias de medicalização da infância, livro organizado por Sandra Caponi, Marua Fernanda Vásquez-Valencia e Marta Verdi, publicado em 2016.

Agradecemos a todas e a todos que colaboraram com este número. Boa leitura!

Caroline Jaques Cubas Joana Vieira Borges Organizadoras 